\title{
From E-Learning to M-Learning - The Use of Mixed Reality Games as a New Educational Paradigm
}

\author{
doi:10.3991/ijim.v5i2.1463 \\ F. Fotouhi-Ghazvini ${ }^{1,2}$, R. A. Earnshaw ${ }^{1}$, A.Moeini ${ }^{3}$, D. Robison ${ }^{1}$, P. S. Excell ${ }^{4}$ \\ ${ }^{1}$ University of Bradford, UK \\ ${ }^{2}$ University of Qom, Iran \\ ${ }^{3}$ University of Tehran, Tehran, Iran \\ ${ }^{4}$ Glyndŵr University, Wrexham, UK
}

\begin{abstract}
This paper analyses different definitions of mobile learning which have been proposed by various researchers. The most distinctive features of mobile learning are extracted to propose a new definition for Mobile Educational Mixed Reality Games (MEMRG). A questionnaire and a quantifying scale are designed to assist the game developers in designing MEMRG. A new psycho-pedagogical approach to teaching is proposed for MEMRG. This methodology is based on the theme of 'conversation' between different actors of the learning community with the objective of building the architectural framework for MEMRG.
\end{abstract}

Index Terms-Mobile Learning, Educational Games, Mixed Reality, Conversational Framework

\section{INTRODUCTION}

Mobile learning is a new educational paradigm which is more flexible than learning which uses desktop computers. Often technology acts as a supplement when PCs are used, whereas with mobile devices the technology can be more integrated with the learning process. It is also portable from one environment to another, such as classroom to outdoors and from outdoors to home. It thus allows the potential of seamless learning to be realised, where the technology mediated the learning is flexible and adaptable so that teacher and student are not bound to a particular learning space. Mobile learning also utilises real-world or situational data to make the learning experience more meaningful and memorable.

Klopfer [1] provides a number of reasons why using computer rooms in educational institutions could present challenges to the learner, if not difficulties. It is noted that:

1. "Computer rooms are located in another place" [1, $\mathrm{p}$ 62] and not in the classroom; students have to change their location and work in unfamiliar surroundings.

2. "Access is irregular" [1, p 63] due to the limited number of computers, scheduled time to use the computer room might not happen at the same time as the learning material is being taught in the class.

3. "Computer labs are not maintained" [1, p 63] due to the limited number of technical staff.

4. "Computer labs are not conducive to teaching” $[1, p$ 63] and it is difficult for teachers to walk in a crowded computer room and check students' work.
5. "Computer labs are not conductive to learning." It is hard to walk and talk, and face-to-face collaborative work is very unlikely. It is also noted with regard to computer-based learning that "activities involve spending the majority of time interacting with computer. Opportunities for real world interactions with partners and classmates are rare" [1, p 64].

It can be inferred that computer-based learning in most schools and universities could impose a barrier to learning and sometimes slow down the process rather than facilitate it. Learning in nature is intrinsically mobile. Reference [2] noted "learning is mobile in terms of space, i.e. it happens at the workplace, at home, and at places of leisure; it is mobile between different areas of life, i.e. it may relate to work demands, self-improvement, or leisure; and it is mobile with respect to time, i.e. it happens at different times during the day, on working days or on weekends". Mobile learning is not bound by time and space and can appropriately enhance the process of learning, especially in an academic environment. It can take place in a classroom, be used frequently, and with no requirement for maintenance. Students can collect data with their camera, share information using Bluetooth, and collaborate faceto-face in an educational mobile game. Mobile learning forms a flexible and adaptable learning environment that can be used for education independent of time and physical location.

M-learning environments fall into two categories:

I. Field-work - where the learner is experiencing realworld situations, continuously communicating through the mobile device and using mobile resources as a reference, or as an assessment tool - in this case materials are designed to be simple and effective.

II. Classroom-based - which often utilizes virtual worlds to inform and engage the learners via multimedia content.

A rich mobile learning system would include both of these environments and combine them into one framework. For example, mobile mixed reality games could be played in a classroom and at the same time use real world data. This system would take into account the mobility of the learners, would help to strengthen the interaction among learners located in the same place, and would assist in creating a virtual mobile arena to learners that are 
geographically distributed using web, SMS and telephone calls. This approach develops a situated learning experience through physical encounters and social interactions, forming a ubiquitous, learner-centered, individualized learning experience which uses mobile technology to network learners into collaborative teams of explorers.

\section{Mobile LEARNING DEFINITIONS}

A range of definitions of mobile learning has been proposed in the literature. In this section they have been divided into four main categories: 'technology oriented', ' $e$ learning oriented' 'location oriented' and 'communication interaction-oriented'. These definitions may overlap and be similar on some points and differ on others.

\section{A. Technology-Oriented Definitions}

These definitions describe mobile learning in terms of mobile devices and related technology, such as mobile phones, PDA, Nintendo DS, PlayStation Portable, iPod, etc, and mobile communication and networking. Reference [3] defined mobile learning as learning that takes place with the help of mobile devices. Reference [4] considered the mobile learning educational process "as any learning and teaching activity that is possible through mobile tools or in settings where mobile equipment is available". Reference [5] states "in the course of personto person mobile communication", whose "site of production, circulation, and consumption is the network' [6]. Reference [7] broadens these definitions into a mobile access 'to use learning service at any time, from any place, quickly and simply, through a simple mobile device, a PDA, a tablet PC, a pocket PC, a "converged device”... with the ability to connect to a broad range of wireless network'. In this approach the pedagogical aspects of mlearning are completely ignored. It assumes no guidelines for teachers and content designers and falls short of a suitable definition of m-learning.

\section{B. Electronic (e) Learning-Oriented Definitions}

This viewpoint characterizes mobile learning as an extension of e-learning. Reference [8] defines mobile learning as 'e-learning that uses mobile devices and wireless transmission'. Reference [9] defined m-learning as the delivery of electronic learning materials on mobile computing devices to allow access from anywhere and at anytime. There have been attempts to create mobile versions of Learning Management Systems (LMS) such as Joomla, Drupal and Moodle for access through mobile phones [10]. Other specialised LMSs such as Mobilim have been also developed to help students to access educational content through mobile devices [11].

This mode of classification often fails to recognise the major differences between m-learning and e-learning. Elearning is often used in formal distance learning while mlearning is semi-formal and used to bridge the gap between formal learning and informal learning. In fieldwork category of m-learning, the communication facilities of the device allow the learner to utilise the teacher's or the expert's guidance, which adds a formal element to the informal setting of the field. In classroom-based $\mathrm{m}$ learning, the virtual spaces such as mobile games add the informal ingredient to the formal setting of the classroom. Table I shows how the m-learning utilises the variable, mobile and spontaneous nature of informal learning while
TABLE I.

A COMPARISON BETWEEN TRADITIONAL FORMAL LEARNING, TRADITIONAL INFORMAL LEARNING AND SEMIFORMAL MOBILE LEARNING

\begin{tabular}{|c|c|c|c|}
\hline & $\begin{array}{l}\text { Formal E- } \\
\text { Learning }\end{array}$ & $\begin{array}{l}\text { Traditional } \\
\text { Informal } \\
\text { Learning }\end{array}$ & $\begin{array}{c}\text { Semi-Formal } \\
\text { Mobile Learning }\end{array}$ \\
\hline $\begin{array}{l}\text { Learning Con- } \\
\text { tent (LC) }\end{array}$ & $\begin{array}{l}\text { Set by the } \\
\text { teacher ac- } \\
\text { cording to the } \\
\text { curriculum }\end{array}$ & $\begin{array}{l}\text { Students de- } \\
\text { rive their own } \\
\text { (LC) accord- } \\
\text { ing to their } \\
\text { learning needs }\end{array}$ & $\begin{array}{l}\text { Set by the teacher } \\
\text { according to the } \\
\text { curriculum, more } \\
\text { content accessible } \\
\text { for further re- } \\
\text { search }\end{array}$ \\
\hline $\begin{array}{l}\text { Learning } \\
\text { Modules }\end{array}$ & $\begin{array}{l}\text { Large and } \\
\text { fixed }\end{array}$ & $\begin{array}{l}\text { Variable in } \\
\text { size according } \\
\text { to the context }\end{array}$ & $\begin{array}{l}\text { Short and context } \\
\text { driven }\end{array}$ \\
\hline $\begin{array}{l}\text { Learning } \\
\text { Route }\end{array}$ & $\begin{array}{l}\text { Activities set } \\
\text { by the teacher }\end{array}$ & $\begin{array}{l}\text { Planned by the } \\
\text { students }\end{array}$ & $\begin{array}{l}\text { Could be planned } \\
\text { by both teacher } \\
\text { and students. } \\
\text { Students often } \\
\text { negotiate with } \\
\text { other peers }\end{array}$ \\
\hline $\begin{array}{l}\text { Learning } \\
\text { schedules }\end{array}$ & Fixed & Variable & Fixed/Variable \\
\hline $\begin{array}{l}\text { Learning } \\
\text { Space }\end{array}$ & Fixed & Mobile & $\begin{array}{l}\text { Mobile, could use } \\
\text { a mixture of vir- } \\
\text { tual spaces with } \\
\text { real spaces }\end{array}$ \\
\hline $\begin{array}{l}\text { Context } \\
\text { Awareness }\end{array}$ & none & $\begin{array}{l}\text { Happens in } \\
\text { context }\end{array}$ & $\begin{array}{l}\text { Happens in con- } \\
\text { text and is aware } \\
\text { of the context }\end{array}$ \\
\hline $\begin{array}{l}\text { Connectivity of } \\
\text { Technology }\end{array}$ & $\begin{array}{l}\text { Limited to } \\
\text { certain areas } \\
\text { with accessi- } \\
\text { bility to a PC }\end{array}$ & Accidental & On demand \\
\hline $\begin{array}{l}\text { Group Forma- } \\
\text { tion }\end{array}$ & Planned & Ad hoc & Ad hoc \\
\hline
\end{tabular}

allowing the learner to assimilate a curriculum and benefit from just in time instructions.

On the other hand m-learning is more suitable for situated learning, where learning happens in the same physical or stimulated context that the knowledge applies. Learners can dialog with virtual or real gurus (i.e. apprentice) in a real life manner through discovery processes, such as Outbreak@MIT game [1]. However in e-learning heavy emphasis is on learning repositories where the construction of content and the nature of interactions is fixed and predetermined by LMS. E-learning can use significant bandwidth with no limitation on textual or multimedia content, but m-learning uses slower mobile transmission techniques such as GPRS with considerable limitation on media access and storage. In addition m-learning is mobile, spontaneous and always connected which helps students to learn in a constructive realistic environment which is dynamic.

\section{Location Oriented Definitions}

There are definitions of m-learning that are more centred around the learner, his/her mobility and the locational context. Reference [12] defines m-learning as: "any sort of learning that happens when the learner is not at a fixed, predetermined location, or learning that happens when the learner takes advantage of the learning opportunities offered by mobile technologies." Reference [13] distinguishes mobile learning "by rapid and continual changes of context, as the learner moves between locations and 
encounters localized resources, services and co-learners", This approach has been accommodated in m-learning research and methodology and it does reveal a distinguishable feature of m-learning through location-centric learning. However, it still overlooks the pedagogical aspects of learning. Most locational m-learning systems are not much more effective than traditional teaching and in reality mobile maps and locational resources which are not built around a constructive framework of learning could be replaced by pen and paper.

\section{Communication Interaction-Oriented Definitions}

This definition emphasises communication and conversation in context. It considers the mobility of the learner during formal or lifelong learning. It regards learning as a constructive and social process. It analyses learning as a personal and situated activity facilitated by technology. Reference [14] defines communication interactionoriented mobile learning as "the processes of coming to know through conversation across multiple contexts amongst people and personal interactive technologies". This definition of m-learning uniquely encompasses the exceptional spirit of m-learning which is to become informed from other people's 'informings' by changing the context which is created as a result of negotiation and dialogue between people facilitated by technology.

\section{E. Discussion of Definitions}

Approaches that begin with technology alone have generally felt to be suspect simply because they are primarily technology driven and, initially at least, leave the user out of account. Theories of human learning have emphasised that pedagogical requirements should come first and then an appropriate learning environment is mediated to the learner by an appropriate selection of the technology that best furthers the pedagogic aims and objectives and meets the pedagogic requirements. To put technology first undermines this educational process and runs the risk of providing the learners with the latest gadgets without any underpinning educational foundations or purpose. In Reference [15] an adventure quiz game is designed for mobile phones but the quizzes are not related to the game story. Students do not pay attention to the quizzes and they are considered as distractions to the gameplay, so no meaningful pedagogical benefits resulted from these games.

Approaches that see m-learning as e-learning with mobile devices may underestimate the significant contribution that context and participative interaction play in the experience of the learner. If a mobile device is only delivering e-learning materials at a distance, it is little different from traditional e-learning [10 and 11].

Similarly, location-centred learning without a pedagogical framework may not advance real learning or use the location to best advantage (e.g. by incorporating it directly into the learner environment and the learner experience). Reference [1, page 120] identifies students that were involved in a locational game play but could not understand the concept of the outdoor portion. During the game students were running around collecting different types of information at different locations, but they could not understand why this information had not been given to them at first place. The learning activity was considered inefficient by students. If the location becomes a place where paradigms are tested and experiments conducted then it is likely to live in the memory of the learner as a reference point - rather like a real chemistry laboratory does for a chemistry student. Theory and practice can then be understood by the learner as different aspects of the same fundamental principle, and also that you cannot have one without the other. Learning is facilitated by seeing a theory or concept demonstrated in real-world examples and demonstrations.

Understanding m-learning as communication and interaction processes highlights the importance of understanding the relationship between the learners and the educational environment, and also between the learners in a group context (in that they can learn from each other to some degree as they are involved together in the learning process). However, without an underlying pedagogical framework such communication and interaction can be ad hoc and lack a well-defined goal. Learning on this basis can be accidental and serendipitous rather than structured and defined. The learners in the group then receive a social experience but not necessarily an educational one [16].

A balanced definition seeks to give primary weight to the pedagogical needs and requirements and the framework within which the educational objectives will be advanced. Technology will be utilised that effectively and efficiently implements these pedagogical goals. Communication and interaction will be facilitated, and the locations of the learners will be utilised as an integral part of the learning process in order to harness the learner's contextual and real-world experiences to further the learning process.

\section{Distinctive FeAtures OF MOBILE LEARNING}

Mobile devices such as mobile phones often cost less than desktop computers and are able to be owned by many people, even the underprivileged in developing countries. Users are able to carry these devices all the time because they are small in size, portable and wearable - often in the pocket or handbag. They have long battery life and they do not need a mains connection as much as laptops. Mobile phones can be switched on and operated immediately. They are easy to use and have useful functionalities, especially for instant communication. They are not obtrusive and can be used to collect, record, capture and store data. Consequently mobile phones can be carried by users all the time and therefore can support mobile learning. Reference [17] defines the different aspects of mobility in mobile learning as follows -

1. 'Mobility in physical space' which helps the learner to carry the mobile device comfortably all day long, everyday and learn in spare moments. They are not bound to a certain location like a classroom, for example in [18], the MOBO city game helps the university students to acquire technical vocabularies on the move while travelling, at home or in restaurant with no requirement to be present in a particular physical environment.

2. 'Mobility of technology' makes it possible for technologies such as Bluetooth, Mobile Web, WiFi, GPS and a camera to come together in a lightweight device ready for utilization whenever required. Reference [19] presented the Detective game which used a mobile phone's camera, Bluetooth and mobile web to help a virtual character 'Detective Alavi' to solve a mystery using a language acquisition process. 
3. 'Mobility in conceptual space. The learner can move from topic to topic, concept to concept and learn in small chunks whenever necessary through the mobile web. In [20], teachers use mobile web to study different language learning comprehensions in their spare time.

4. 'Mobility in social space'. The mobility of the learner in physical space facilitates the forming of different groups during the day for collaborative learning. In [18], MOBO city is not a multiplayer game. However as the learner plays the mobile game at different locations, different groups of students are attracted to the game and therefore help the learner by forming a social space. In [19] players are able to play against any other group of learners using a Bluetooth ad hoc connection.

5. 'Learning dispersed in time'. The learning can be distributed across different point in time and increasingly built up. In [19], the Detective game builds knowledge in a hierarchical fashion. The players are able to save their scores and cognitive progress and come back to the game when appropriate.

Different dimensions of mobility result from the contextual and communicative features of mobile learning.

\section{A. Contextual}

Mobile learning occurs across different contexts. A system is regarded as context-aware "if the system uses context to provide relevant information and/or services to the user, where relevancy depends on the user's task" [21]. The learner has a situated role while being able to use the contextualized information in a mobile device readable form [22]. A mobile learning context definition has been given as "any information that can be used to characterize the situation of learning entities that are considered relevant to the interactions between a learner and an application" [23]. Reference [24] presents a significant difference between context as "that which surrounds us" and context as "that which weaves together". In a mobile learning context is not just a shell to surround mobile learners, but it increases interaction and engagement between learners and the learning environment.

\section{B. Different Types of Context}

Factors that contribute to creating context in mobile learning are the learners' interaction with system, the mobile device, wireless infrastructure, environment and other learners. Different context types exist in mobile learning environments and these are discussed below.

\section{1) Spatio-Temporal context}

This context type depicts the characteristic of a learner's context regarding time and spatial aspects. Sensors such as GPS, compass, Bluetooth, camera, accelerometer and gyroscope are part of today's mobile device and collect ambient information in the form of (A) temporal context, in this case the mobile device is aware of time-dependent data and provides temporal information to the learner concerning the period during which some event happened or will occur [23], (B) spatial context are : (1) absolute position of the mobile device provided by combination of GPS (Global Positioning System) receiver and compass [25] (2) relative position of the mobile device provided by Bluetooth [19] (3) relative position and orientation of a physical object to the mobile devices' camera using QR codes or augmented reality markers to discover the embedded text, activate a web browser, make a phone call [19] or overlay the physical object with virtual text, graphics or audio [26] (4) orientation of the mobile device measured by combination of accelerometer and gyroscope [27].

\section{2) Device Context}

Device context provides a basis for exploiting the potential of hardware and software and the capabilities of the device. Access to different services is provided according to the device context. Information such as location, camera, communication tools, screen size, browser types, bandwidth, connectivity, battery, operating systems, amount of available memory and processing power are essential for detecting the kind of services that could be installed or accessed through the device [28].

\section{3) Virtual World Context}

This provides computational data concerning events occurring within the virtual environment of the mobile learning system. It assigns goals, modules, calculates the current state of the learner in learning activity, monitors the learner's progress, the learner's grades or scores, and the current state of the teaching procedure such as specifying the next step of instruction or what learning resources must be utilised [29].

\section{4) Personal Context}

This could be divided into three parts: physiological, mental and biographical. The first part includes information such as name, nationality, gender, address, physical feature, disabilities etc. The second part contains information such as learning habit, mood, interest, and hobbies etc. The third part includes information such as qualifications achieved, job experiences and training, skills gained, affiliations, modules registered etc [29].

\section{5) Role Context}

The learner uses this information to assist with the social role in collaborative learning. Role context provides information about the learning system's virtual characters and information from other users such as the learners, friends, colleagues, teacher, supervisor or advisor in a peer-to-peer networked mobile learning environment [29].

\section{Level of Interactivity}

Mobile context-aware applications include two levels of interactivity: (1) active context aware applications, and (2) passive context aware.

\section{1) Active Context-aware application}

In this mode, sensors obtain contextual data and the application automatically updates a service for the learner. For example in [30] visual codes are distributed in different locations in a museum, and the application uses these codes to instantly connect the learners to specific webbased information. In this mode, learners are less in control and are passive. On the other hand the application does the entire work and is proactive [29]. This process could consume a considerable amount of time and resources, but user input is minimised and learners are less distracted.

\section{2) Passive context-awareness}

In this approach the application is passive and only shows the changes in the context. However, the learner actively participates and analyses contextual information 
via the interactive interface of the application, and makes decisions if it is appropriate to apply changes such as location or time [30].

\section{Communicative}

Mobile learning systems are able to use wireless or mobile phone connectivity such as Bluetooth, Infrared, WiFi, phone calls, SMS, MMS or mobile web to connect people across contexts. This mode of connectivity allows students to build learning communities that facilitate conversations between learners in real and virtual worlds. In mobile social interactivity, learners converse, share and interrogate their perspectives on subject matter, negotiate, send and receive feedback to and from others, share data, aggregate and distribute them with other learners, experts or teachers forming a collaborative learning environment. This could considerably increase the engagement [31] among learners and provide a significant boost to the learner's confidence [32].

\section{MobILE GAMES}

\section{A. Mobile Games and Learning}

Learning can be facilitated by the effective combination of different kinds of resources and different modes of developing knowledge and skills. Mobile learning helps the learners to take advantage of the learning opportunities offered by mobile technologies through the use of mobile devices such as mobile phones and Personal Digital Assistants (PDAs) in contextualised authentic settings. This mode of learning enables learners to interact simultaneously with both the physical world and with the virtual world of digital information. Combining familiar actions in the physical environment with new information in the virtual world promotes a new experience with more engagement and higher social learning among learners. Information in digital space can be translated into game content characteristics: concepts, topics, and tasks. Game based learning is greatly satisfying and fast-paced compared to repetitive and boring tasks in schools [33]. Educational games have demonstrated by careful design that they are able to offer a flow experience that immerses the learners in active learning and are able to boost the intrinsic motivation level of a learner by means of highly engaging challenges and feedback [34 and 35]. Given recent progress in mobile and wireless technologies, it makes sense to consider combining mobile learning with gamesbased learning.

Mobile games are often played in mutual tolerance of players' other daily activities such as walking in a park or a street. The game system depends to some degree on external input such as the players' proximity from each other or the player's location. Players receive different questions and hints as their physical position varies and they can switch attention between activities to play the game. These games take place in the real world and contain nonplayers; consequently, each game session can produce different experiences. In order to obtain the players' context, each player's mobile device is augmented with an array of software or hardware features, such as Global Positioning System (GPS) device, Radio Frequency Identification (RFID) reader, Bluetooth, Infrared or decoding software and camera for taping into $\mathrm{QR}$ codes and other visual code information.
These games can be very innovative and can belong to different game genres. Mixed reality games are one of the most exciting genres that are often very difficult and impractical to implement on other platforms especially for educational purposes. Mobile games can use the mobile platform's distinctive features to implement this genre for classroom activities and field work. This leads to new types of game which are termed in this research a 'Mobile Educational Mixed Reality Game' (MEMRG).

\section{B. Mixed Reality Games}

To define the concept of mixed reality games, Milgram [34] introduced the concept of 'Virtuality Continuum'. Reference [34] defines this as a 'mixture of classes of objects presented in any particular display situation'. At one end of his scale is a 'virtual environment' which consists of only virtual objects and graphical simulation. At the other end is a 'real environment' with real objects that can be sensed directly. Mixed reality environments are defined by Reference [36] as applications where real world and virtual world objects are presented together within a single display, that is, anywhere between the extrema of the virtuality continuum,. From reference [36] it can be inferred that the emphasis from the mixed reality definition is on real world and virtual world objects superimpose. Reference [37] studied mixed reality environments formed by mixing real and virtual spaces together in different ways; and display is only one of these. These spaces are not superimposed but are placed adjacent to each other and a window is created between them. According to this research a mixed reality system could have multiple boundaries to many distributed spaces. These separate spaces form a bigger super-space where they can complement each other, share information and increase social interactions.

\section{MEMRG and the Semantic Concept}

In an educational setting the most important element that is transmitted, received, shared and discussed is information. Here we describe 'Semantic' as meaningful information that is necessary for the game to operate, or for a learning objective to be achieved. It is extracted from mobile device's sensors or different virtual game space processes. Ideally, semantic leads to 'assessing', 'instructing' or 'motivating' the learners in the process of 'knowledge acquisition' or 'knowledge construction'. Semantics are often in the form of (1) text, graphic, audio, other player's scoring data extracted from the virtual game space or cyber world space, (2) location and orientation data from the real world (3) audio or text from mobile space or any other type of information that could be picked up with our five senses. For example, in the Live Long and Prosper game [1] the semantics were in the form of location data and the game's virtual space data (the gene's compatibility). In the Environmental Detective and Outbreak@MIT games [1] the semantics were in the form of location data, audios, texts, videos. In the Savannah game [38] semantics were in the form of smells, sounds, texts, graphics, and location data were semantics. In these games' user interface we cannot observe that at any moment in the game play, real objects visually superimpose virtual objects. This trend is evident in most MEMRG projects. The important limitation in this kind of mixed reality games is to maintain the 'flow' of the game when shifting from real space to virtual space and vice versa. 
MEMRG must be able to combine mixed physical/virtual space with the mobile space for conversation and information exchange, and also be connected to cyberspace for accessing multimedia information, collaborative tools and conversational possibilities which are all encapsulated in a semantic learning space. Figure 1 (situated at the end of paper) represents a MEMRG learning space where mobile, cyber, virtual and real spaces are placed next to each other. There are close boundaries between the spaces but they do not superimpose. The virtual space has a pivotal role for different processes such as image processing, decoding, extracting locational data, educational assessment and instruction. The window to real, mobile and cyber spaces are provided by different interfaces that increase the accessibility of the game for the players. Data flow in MEMRG is carried out by different semantics. Their type 'mobile', 'cyber', 'real' and 'virtual' depends on where they have been originally generated. Different sensors such as GPS, Bluetooth, camera and accelerometer generate location and orientation semantics. However when decoding a QR code captured by a camera, alphanumeric semantics such as a phone number, a URL address, an SMS template or just pure text could result. Learners also extract and use semantic information from the mobile space and cyberspace without relying on any software during phone calls, SMS conversations and mobile web searches. They use their own perceptions through collaborative work with peers to extract the necessary semantics.

Not all of the sensors in Figure 1 are necessary for a mixed reality game. Object recognition using markers and augmenting the real world with graphic and audio is more suitable for natural sciences like physics, biology and chemistry where observation, experience and experiment are important. In the case of geography and history GPS could be valuable for encompassing large areas. In Engineering, and social sciences like linguistic, law and philosophy that are more analytical and critical, communication facilities like phone calls, mobile web and Bluetooth connections are helpful.

\section{MEMRG and Mobility, Context and Communication Features}

To support MEMRG mobility, contextual and communication features must be included. These introduce new opportunities for learning. Instructional content designers need to exploit the true nature of this novel approach. It is essential to consider important aspects of mobility, context and communication in mobile learning. To facilitate this process the following table provides a questionnaire for MEMRG designers to measure the degree of mobility, context and communication in their game by acquiring positive answers to the questions.

TABLE II.

A QUESTIONNAIRE TO MEASURE THE DEGREE OF MOBILITY, CONTEXT AND COMMUNICATION IN MEMRG

\begin{tabular}{|l|l|}
\hline Degree of mobility in a MEMRG \\
\hline & $\begin{array}{l}\text { 1- Is the learner able to take your game and play it in the } \\
\text { gaps between work? }\end{array}$ \\
\cline { 2 - 3 } & 2- Is your game free of bounding to certain location? \\
\cline { 2 - 2 } & 3- Does your game utilise Bluetooth or Infrared? \\
\cline { 2 - 2 } & 4- Does your game utilise WiFi, GPRS or 3G? \\
\cline { 2 - 3 } & 5- Does your game utilise GPS? \\
\cline { 2 - 2 } & 6- Does your game utilise mobile camera? \\
\hline
\end{tabular}

\begin{tabular}{|c|c|}
\hline & 7- Does your game utilise SMS or MMS? \\
\hline & 8- Does your game utilise phone calls? \\
\hline & $\begin{array}{l}\text { 9- Does you game allow the learner to move from topic to } \\
\text { topic? }\end{array}$ \\
\hline & 10- Does your game allow forming different groups? \\
\hline & $\begin{array}{l}\text { 11- Does your game allow learning that is accumulated at } \\
\text { different points in time? }\end{array}$ \\
\hline \multicolumn{2}{|c|}{ Degree of context in a MEMRG } \\
\hline \multirow{6}{*}{$\begin{array}{c}\text { Spatio- } \\
\text { Temporal } \\
\text { Context }\end{array}$} & 1- Is your game aware of time? \\
\hline & $\begin{array}{l}\text { 2- Does your game provide temporal information to the } \\
\text { learner? }\end{array}$ \\
\hline & $\begin{array}{l}\text { 3- Does your game utilise absolute position of the mobile } \\
\text { device? }\end{array}$ \\
\hline & $\begin{array}{l}\text { 4- Does your game utilise relative position of the mobile } \\
\text { device? }\end{array}$ \\
\hline & $\begin{array}{l}\text { 5- Does your game utilise relative position and orientation } \\
\text { of a physical object? }\end{array}$ \\
\hline & $\begin{array}{l}\text { 6- Does your game utilise orientation of the mobile de- } \\
\text { vice? }\end{array}$ \\
\hline \multirow{5}{*}{$\begin{array}{l}\text { Device } \\
\text { Context }\end{array}$} & $\begin{array}{l}\text { 1- Is your game designed considering information about } \\
\text { device screen size and resolution? }\end{array}$ \\
\hline & $\begin{array}{l}\text { 2- Is your game designed considering information about } \\
\text { available device memory? }\end{array}$ \\
\hline & $\begin{array}{l}\text { 3- Is your game designed considering information about } \\
\text { device processing power? }\end{array}$ \\
\hline & $\begin{array}{l}\text { 4- Is your game designed considering information about } \\
\text { mobile internet bandwidth? }\end{array}$ \\
\hline & $\begin{array}{l}\text { 5- Is your game designed considering information about } \\
\text { device's operating system and software capabilities? }\end{array}$ \\
\hline \multirow{7}{*}{$\begin{array}{l}\text { Virtual- } \\
\text { World } \\
\text { Context }\end{array}$} & 1- Does your game assign learning goals? \\
\hline & 2- Does your game assign the learning modules or topics? \\
\hline & $\begin{array}{l}\text { 3- Does your game calculate current state of learner inter- } \\
\text { activity? }\end{array}$ \\
\hline & 4- Does your game calculate learner's progress? \\
\hline & 5- Does your game calculate learner's score? \\
\hline & 6- Does your game calculate current state of teaching? \\
\hline & 7- Does your game calculate other team's progress? \\
\hline \multirow{3}{*}{$\begin{array}{c}\text { Personal } \\
\text { Context }\end{array}$} & $\begin{array}{l}\text { 1- Is your game designed considering physiological as- } \\
\text { pects of learner? }\end{array}$ \\
\hline & $\begin{array}{l}\text { 2- Is your game designed considering mental conditions } \\
\text { of learner? }\end{array}$ \\
\hline & $\begin{array}{l}\text { 3- Is your game designed considering biographical infor- } \\
\text { mation of the learner? }\end{array}$ \\
\hline \multirow{5}{*}{$\begin{array}{c}\text { Role } \\
\text { Context }\end{array}$} & $\begin{array}{l}\text { 1- Does your game help the learner to have a social role } \\
\text { according to other learners? }\end{array}$ \\
\hline & $\begin{array}{l}\text { 2- Does your game help the learner to have a social role } \\
\text { according to virtual characters? }\end{array}$ \\
\hline & $\begin{array}{l}\text { 3- Does your game help the learner to be acknowledged } \\
\text { about social roles of other learners? }\end{array}$ \\
\hline & $\begin{array}{l}\text { 4- Does your game help the learner to be acknowledged } \\
\text { about social roles of virtual characters? }\end{array}$ \\
\hline & $\begin{array}{l}\text { 5- Does your game help the teacher to have a social role } \\
\text { according to learners? }\end{array}$ \\
\hline \multicolumn{2}{|c|}{ Degree of communication in a MEMRG } \\
\hline & $\begin{array}{l}\text { 1- Does your game encourage learners to converse and } \\
\text { collaborate with other learners? }\end{array}$ \\
\hline & $\begin{array}{l}\text { 2- Does your game encourage learners to share informa- } \\
\text { tion? }\end{array}$ \\
\hline & $\begin{array}{l}\text { 3- Does your game encourage learners to offer their own } \\
\text { ideas and understanding? }\end{array}$ \\
\hline & $\begin{array}{l}\text { 4- Does your game encourage the learners to participate } \\
\text { in discussion and debate? }\end{array}$ \\
\hline
\end{tabular}




\begin{tabular}{|l|l|}
\hline & $\begin{array}{l}\text { 5- Does your game encourage learners to compete with } \\
\text { other learners? }\end{array}$ \\
\cline { 2 - 3 } $\begin{array}{l}\text { 6- Does your game encourage learners to ask questions } \\
\text { from the teacher? }\end{array}$ \\
\cline { 2 - 2 } $\begin{array}{l}\text { 7- Does your game encourage learners to present ideas to } \\
\text { the teacher? }\end{array}$ \\
\cline { 2 - 2 } $\begin{array}{l}\text { 8- Does your game provide a method for teachers to send } \\
\text { feedback to learners? }\end{array}$ \\
\hline
\end{tabular}

There are two choices of 'yes' and 'no' available to each question. Table below explains how we quantify the results from the questionnaire. We have scored the various categories and responses and we devised a scale from 'Very Good' down to 'Very Poor', to show how we measure the degree of mobility, context and communication. We regard 'very poor' and 'poor' as unacceptable levels of responses and 'moderate', 'good' and 'very good' as acceptable levels of responses.

TABLE III.

A DEVISED SCALE TO OUANTIFY MEMRG QUESTIONNAIRE RESPONSES FROM TABLE 1

\begin{tabular}{|c|c|c|}
\hline \multirow{4}{*}{ Degree of mobility } & $\begin{array}{c}\text { Number of positive } \\
\text { answers }\end{array}$ & $\begin{array}{c}\text { Level of accep- } \\
\text { tance }\end{array}$ \\
\cline { 2 - 3 } & 1,2 & Very poor \\
\cline { 2 - 3 } & 3,4 & poor \\
\cline { 2 - 3 } & 5,6 & moderate \\
\cline { 2 - 3 } & 7,8 & good \\
\hline \multirow{4}{*}{\begin{tabular}{c} 
Degree of context \\
\cline { 2 - 2 }
\end{tabular}} & $9-11$ & very good \\
\cline { 2 - 3 } & $1-4$ & very poor \\
\cline { 2 - 3 } & $5-9$ & poor \\
\cline { 2 - 3 } & $10-14$ & moderate \\
\hline \multirow{4}{*}{$\begin{array}{c}\text { Degree of communica- } \\
\text { tion }\end{array}$} & $15-19$ & good \\
\cline { 2 - 3 } & $20-26$ & very good \\
\cline { 2 - 3 } & 1 & very poor \\
\cline { 2 - 3 } & 2 & poor \\
\cline { 2 - 3 } & 3,4 & moderate \\
\hline
\end{tabular}

\section{E. MEMRG Limitations}

GPS technology is used for outdoor positioning in mobile games. However its accuracy could be diminished by (1) the level of noise introduced by the signals close to the GPS receiver (2) bad weather conditions (2) multipath reflection and occlusion of the satellite that are due to the barriers around the GPS receiver such as nearby trees, buildings and mountains. Mobile phones transmit and receive radio waves from a service provider's base station while being in the Universal Mobile Telecommunication Service (UMTS) coverage during phone calls, sending SMS and browsing web. This coverage could be affected by the local conditions that are (1) multipath fading where signal might reflect off an object such as a building which leads to signal distortion (2) interference from signals with same frequencies (3) attenuation as the signal passes through a building wall (4) proximity of the phone to the base station (5) weather conditions (6) capacity of the network to handle a specific number of callers (7) signal hand off when travelling from one mobile phone cell to another. Camera phones often do not have the advanced features of the digital cameras to take a sharp and accurate image. Consequently the device might fail to process and decode the QR coders/markers images taken while the camera is being shaken or there are poor light conditions. In the case of markers, if the position and orientation of the physical object is not accurately tracked, the synthetic image is not able to superimpose the object accurately. This prevents the real and virtual space from correctly aligning together.

\section{F. Detective Alavi-An example of MEMRG}

Detective Alavi is a MEMRG whose implementation is described in [19] and in Figure 1 the red arrows show the flow of semantics and different processes and components of this game. The degree of mobility in the game is 9 (i.e. very good), the degree of context 21 (i.e. very good) and the degree of communication 8 (i.e. very good). The game's main canvas depicts a fantasy world of a computer Central Processor Unit (CPU). A mysterious problem has occurred that stopped the CPU from functioning. The mystery requires the 'Detective Alavi' to use his language skills and knowledge of electronics to solve it. Clues to the game's puzzles are distributed through the virtual space's learning resources, the virtual character's conversations, the teacher's feedback and different web sites. The puzzles are located in the real space built by QR codes in the form of puzzles, word games and board games. The QR codes help to connect to the mobile space where there are teachers, experts and more competent peers that are located at different physical locations. During the game they can be contacted by phone calls or SMS. They can offer their explanations and feedback to the students or ask them to present their ideas; in the context of the normal game play and the game story line. Mobile learners can also access the web and search for information that is provided for them as further learning resources, or additional clues to solve the game's challenges. The players interact face to face with each other, ask questions and share ideas. This less restricted style of interaction could help towards enhanced communication skills, better analysis and improved thought processes.

\section{CONCLUSIONS}

MEMRG can be easily implemented in classroom and field-work using mobile devices. This is due to the following three factors (1) mobile devices such as mobile phones have reasonable costs and are available to the players (2) its form factor is suitable for novice players and most game play could take place unsupervised (3) the device is self-contained and fully packaged with necessary sensors and consequently is independent of institution's infrastructure. MEMRG uses mobile technology and is mobile in physical, conceptual and social spaces. It makes use of contextual data such as spatio-temporal, device, virtual world, personal, role, and context. It is able to communicate face to face or at a distance using SMS, MMS, phone calls and mobile web with peers, teachers and experts. Contextual and communication information are extracted by software or via the learner's conceptual abilities into a meaningful form that is defined as semantic. Different forms of semantics are present at various stages in the game play which can be visible or invisible to learners. These semantics build a learning space that weaves together real, virtual, mobile and cyberspace into a uniquely engaging learning environment which facilitates communication between different members of the learning community [19]. 
Audio or text (Mobile Space Semantic)

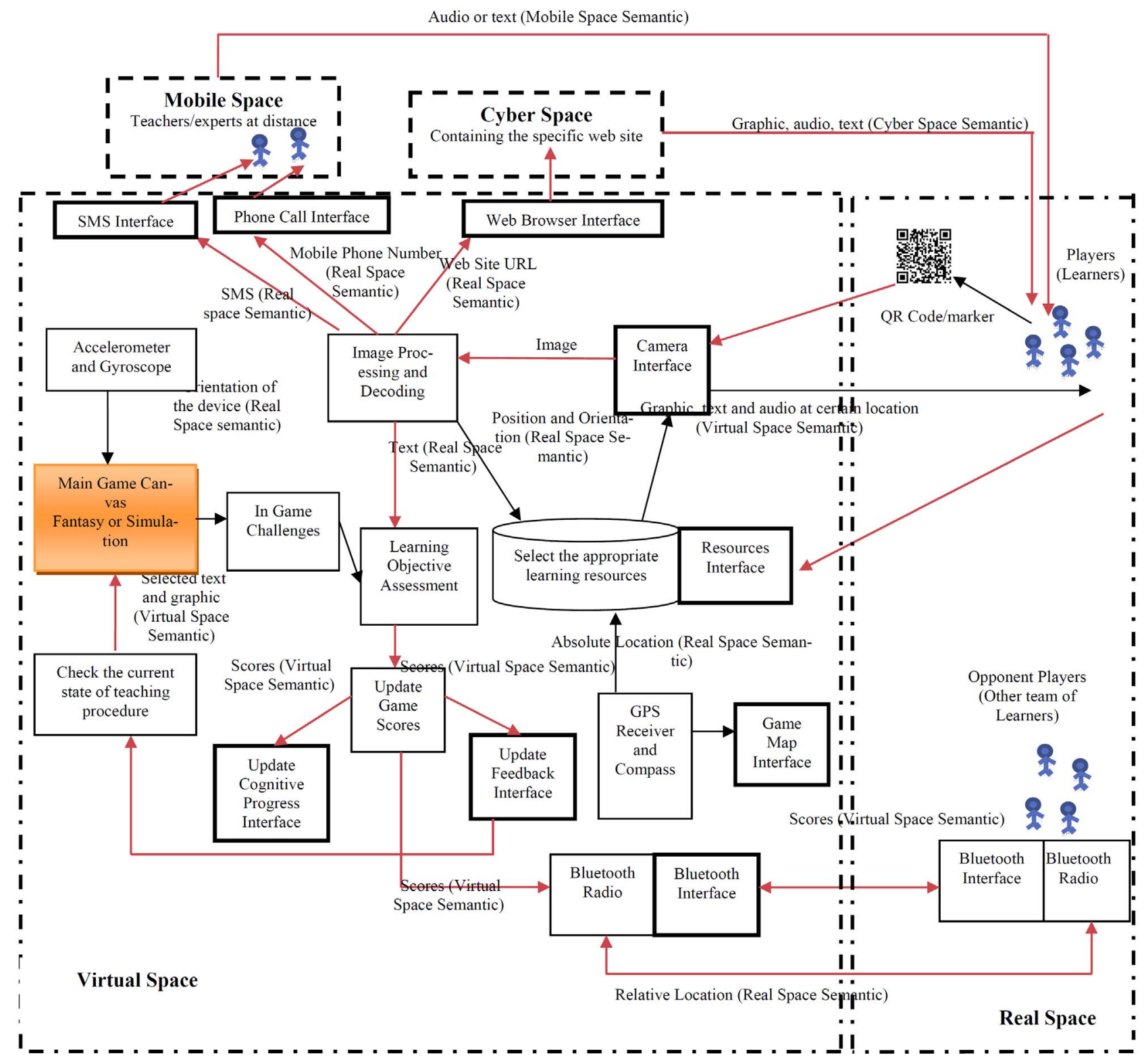

Figure 1. Semantic Learning Space Model for the MEMRG realisation.

\section{REFERENCES}

[1] E. Klopfer, Augmented Learning: Research and Design of Mobile Educational Games, The MIT Press. 2008.

[2] G.N., Vavoula and M.Sharples, "KLeOS: A personal, mobile, knowledge and learning organization system," In: Milrad, M. Hoppe, U., Kinshuk (eds.) Proceedings of the IEEE International Workshop on Mobile and Wireless Technologies in Education, WMTE 2002, Vaxjo, Sweeden, pp. 152-156, 2002.

[3] C. Quinn, "mLearning: Mobile, Wireless, In-Your-Pocket Learning," LiNE Zine. Fall. 2000 [online] Available from: http://www.linezine.com/2.1/features/cqmmwiyp.htm [Accessed: July 2007].

[4] L. Colazzo, A. Molinari, M. Ronchetti, and A. Trifonova, "Towards a Multi-Vendor Mobile Learning Management System," Proceedings for the World Conference on E-learning. Phoenix, USA. 2003 [online] available from: http://www.science.unitn.it/ foxy/docs/Towards $\% 20 \mathrm{a} \% 20$ multivendor $\% 20$ Mobile $\% 20$ LMS\%20(long).pdf [accessed: April 2007]

[5] K. Nyíri, Towards a Philosophy of M-Learning. Proceedings of the IEEE International Workshop on Wireless and Mobile Technologies in Education. pp. 121-124, 2002.
[6] P. Polsani, "Network learning. In K Nyiri K (ed)" Mobile learning essays on philosophy, psychology and education. Vienna: Passagen Verlag, pp. 139-150, 2003.

[7] M.C. Brugnoli and I. Lorusso et al. "MOBIlearn deliverable D12.1-Market study, in Brasher A. MacAndrew P. and Sharples M. (2005) Roadmap for further research on pedagogical issues," MOBIlearn/OU/WP4/4.3/1.0, 2004 [online] Available from: http://www.mobilearn.org/download/results/public deliverables/M OBIlearn_D4.3_Final.pdf [Accessed: April 2010].

[8] N. Pinkwart , H.U. Hoppe, M. Milrad and J. Perez "Educational scenarios for the cooperative use of Personal Digital Assistants," Journal of Computer Assisted Learning, 19 (3), pp. 383-391, 2003. doi:10.1046/j.0266-4909.2003.00039.x

[9] M. Ally, "Using learning theories to design instruction for mobile learning devices," Proceedings of the Mobile Learning 2004 International Conference, Edited by Jill Attewell and Carol SavillSmith, Rome. pp 5-8, 2004.

[10] E-learning (2010) [online]. Elearning LMS available from: http://www.elearninglearning.com/lms/mobile/[Accessed: April 2010].

[11] A. Istanbullu, "Mobilim: Mobile Learning Management Framework System for Engineering Education," International Journal of Engineering Education, Volume 24 (1), pp. 32-39 (8), 2008. 
[12] C. O'Malley, G. Vavoula, J.P. Glew, J. Taylor, M. Sharples, and P. Lefrere, "Guidelines for learning/teaching/tutoring in a mobile environment," MOBIlearn deliverable D4.1 [online], 2003, Available from: http://www.mobilearn.org/download/results/ guidelines.pdf [Accessed: 10 April 2010].

[13] T. Chan, M. Sharples, G. Vavoula, and P. Lonsdale, "Educational Metadata for Mobile Learning", In Proceedings of the 2nd IEEE international Workshop on Wireless and Mobile Technologies in Education (Wmte'04). WMTE. IEEE Computer Society, Washington, DC, page 197, 2004.

[14] M. Sharples, J. Taylor and G. Vavoula, "A Theory of Learning for the Mobile Age," pp. 221-247, 2007.

[15] F. Fotouhi-Ghazvini, A. Moeini, D. Robison, R. A. Earnshaw and P. S. Excell, "A Design Methodology for Game-based Second Language Learning Software on Mobile Phones", Proceedings of Internet Technologies and Applications 2009, pp 609-618, 2009.

[16] D. Laurillard, "The pedagogical challenges to collaborative technologies," Computer-Supported Collaborative Learning, 4(1), Springer New York, pp. 5-20, 2009.

[17] M. Sharples, M. Milrad, Sánchez, I., Arnedillo and G. Vavoula, "Mobile Learning: Small devices, Big Issues," In N. Balacheff, S. Ludvigsen, T. de Jong, A. Lazonder \& S. Barnes (eds.) Technology Enhanced Learning: Principles and Products. Heidelberg: Springer, pp. 233-249, 2009.

[18] F. Fotouhi-Ghazvini, R. A. Earnshaw, D. Robison and P.S.Excell, "The MOBO City: A Mobile Game Package for Technical Language Learning", International Journal of Interactive Mobile Technologies, Vol 3, No 2, pp 19-24, 2009.

[19] F. Fotouhi-Ghazvini, R. A. Earnshaw, A. Moeini, D. Robison, P. S. Excell, "Implementing Mixed Reality Games for Mobile Language Learning", Proceedings of International Conference on Mobile Learning (IADIS), 10-12 March 2011, Spain.

[20] F. Fotouhi-Ghazvini, R. A. Earnshaw, L. Haji-Esmaeili, "Mobile Assisted Language Learning in a Developing Country Context", Proceedings of Cyberworlds 2009, IEEE Computer Society, pp 391-397, ISBN 978-0-7695-3791-7, 2009. doi:10.1109/CW. $\underline{2009.28}$

[21] A. K. Dey, "Understanding and using context," Personal and ubiquitous computing, 5 (1), pp. 4-7, 2001. doi:10.1007/s0077 $\underline{90170019}$

[22] B. Hu and P. Moore "A context Framework supporting contextual and cooperative learning" In Proceedings of IADIS International Conference Mobile Learning. Quara, Malta, pp. 236-240, 2005.

[23] Y-K Wang, "Context Awareness and Adaptation in Mobile Learning," In Proceedings of the 2nd IEEE International Workshop on Wireless and Mobile Technologies in Education, 2004. doi:10.1109/WMTE.2004.1281370

[24] M. Cole, "Cultural psychology: A once and future discipline," Cambridge, MA: Harvard University Press, 1996. [online] Available from: http://5myths.com/Publishing/Whitepapers/SKorea/ All.aspx [Accessed: April 2007].

[25] T. Pederson, C. Ardito, P. Bottoni, and M. F. Costabile, "A General-Purpose Context Modeling Architecture for Adaptive Mobile Services," I.-Y. Song et al. (Eds.): ER Workshops 2008, LNCS 5232, Springer-Verlag Berlin Heidelberg, pp. 208-217, 2008.

[26] T. Y. Liu, T.H. Tan and Y. L. Chu "QR Code and Augmented Reality-Supported Mobile English Learning System", Jiang X., Ma M.Y., and Chen C.W. (Eds.): WMMP 2008, LNCS 5960, Springer-Verlag Berlin Heidelberg, pp. 37-52, 2010

[27] T. J. Mehigan, "Harnessing accelerometer technology for inclusive mobile learning", In Proceedings of the 11th International Conference on Human-Computer Interaction with Mobile Devices and Services (MobileHCI '09). ACM, New York, NY, USA, , Article 100,2 pages. 2009 .

[28] R. Benlamri and X. Zhang, "A Global Ontology Space for Mobile Learning," Eighth IEEE International Conference on Advanced Learning Technologies, pp 49-53, $2008 . \quad$ doi:10.1109/ ICALT.2008.108
[29] B. Hu and Ph. Moore, "SmartContext: An Ontology Based Context Model for Cooperative Mobile Learning," $W$. Shen et al. (Eds.): CSCWD 2006, LNCS 4402, Springer-Verlag Berlin Heidelberg, volume 4402/2007, pp. 717-726, 2007.

[30] K. Mitchell, and N. J. P. Race, " uLearn: Facilitating ubiquitous learning through camera equipped mobile phones," Proceedings of the Third IEEE International Workshop on Wireless and Mobile Technologies in Education, Tokushima, Japan: The IEEE computer society, pp. 274-281, 2005.

[31] G. Stead, M-learning: small, engaging and at your leisure. The Learning Citizen, no. 8, pp10-13, 2004 [Online]. Available from http://www.learningcitizen.net [Accessed: July 2007].

[32] J. Trinder, "Possible Uses of PDAs for Engineering Students with Disabilities," [online] Higher Education Academy Engineering Subject Centre. 2006, Available from: http://www.engsc.ac.uk/ er/dis/pda.asp [Accessed: July 2007].

[33] S. Papert, The Children's Machine: Rethinking School in the Age of the Computers. Basic Books, New York, 1993.

[34] C. Conati, "Probabilistic Assessment of User's Emotions in Educational Games," Journal of Applied Artificial Intelligence, special issue on "Merging Cognition and Affect in HCI", vol. 16 ( 7-8), pp. 555-575, 2002.

[35] T. S. Chan, and T. C. Ahern, "Targeting motivation - adapting flow theory to instructional design," Journal of Educational Computing Research, Vol. 21 (2), pp. 152-163,1999.

[36] P. Milgram, and F. Kishino, "A Taxonomy of Mixed Reality Visual Displays," IEICE Transactions on Information Systems, Vol E77-D (12), pp.1-15, 1994.

[37] S. Benford, C. Greenhalgh, G. Reynard, C. Brown, B. Koleva, "Understanding and Constructing Shared Spaces with MixedReality Boundaries" In ACM Transactions on Computer-Human Interaction, Vol. 5, No. 3, pp. 185-223, 1998 doi:10.1145/ 292834.292836

[38] K. Facer, R. Joiner, D. Stanton, J. Reidz, R. Hullz and D. Kirk, "Savannah: mobile gaming and learning?" Journal of Computer Assisted Learning, Blackwell Publishing Ltd, pp. 399-409, 2004.

[39] D. Laurillard, Rethinking University Teaching: A Framework for the Effective Use of Educational Technology, London: Routledge, 1993.

\section{AUTHORS}

Faranak Fotouhi-Ghazvini is a Lecturer in Mobile Communication at the University of Qom, 37165, Iran and $\mathrm{PhD}$ student at the University of Bradford, UK, BD7 1DP, ffotouhi@bradford.ac.uk

Rae Earnshaw is Professor of Electronic Imaging and Media Communications at the University of Bradford, UK, BD7 1DP, R.A.Earnshaw@Bradford.ac.uk, Tel: +44 (0) 1274-236131

Ali Moeini is an Assistant Professor in Engineering Science and Head of the Informatics Centre at the University of Tehran, Iran. His research interests are in nonlinear systems and expert systems.moeini@ut.ac.ir

David Robison is a Lecturer in Media and Mobile Media at the University of Bradford, UK, BD7 1DP, d.robison@Bradford.ac.uk

Peter Excell is a Professor of Communications and Head of the School of Computing \& Communications Technology at the University of Glyndwor, Wrexham, LL112AW, p.excell@newi.ac.uk

Received October $1^{\text {st }}, 2010$. Published as resubmitted by the authors March 24 $4^{\text {th }}, 2011$. 